\title{
Morphometry of testis and seminiferous tubules of the adult crab-eating fox (Cerdocyon thous, Linnaeus, 1766)
}

\author{
Bianca Cabral Caldeira ${ }^{1}$, Tarcízio Antônio Rêgo de Paula ${ }^{2}$, Sérgio Luis Pinto da Matta ${ }^{3}$, Mayte Koch Balarini ${ }^{1}$, \\ Pamella Kelly Araújo Campos ${ }^{1}$
}

\begin{abstract}
Body and testicular biometric parameters are very important for establishing reproductive patterns and, consequently, the development of protocols for assisted reproduction in different species. A direct correlation between the testis weight and the sperm population was observed in other studied species, because the testis size primarily reflects the total volume of the seminiferous tubule, its main component. The objective of this study was to determine the testicular volume parameters and correlate data from morphometry of testis and seminiferous tubules with body mass in six adult crab-eating foxes. The mean body weight of the crab-eating foxes in this study was $6.53 \mathrm{~kg}$, with approximately $0.068 \%$ allocated to the testicular mass and $0.042 \%$ specifically to seminiferous tubules, which represented $87.5 \%$ of the testicular parenchyma. The albuginea comprised $12.5 \%$ of the testicular mass. The mean diameter of seminiferous tubules was $236 \mu \mathrm{m}$, and the mean thickness of the seminiferous epithelium was $62.9 \mu \mathrm{m}$. Values of tubular parameters indicate a sperm productivity close to those observed in previously studied carnivores.
\end{abstract}

Key words: Morfology, testis, crab-eating fox, Cerdocyon thous, gonadosomatic index.

\section{RESUMO}

\section{Morfometria testicular e de túbulos seminíferos do cachorro-do-mato (Cerdocyon thous, Linnaeus, 1766) adulto}

Os parâmetros de biometria corporal e testicular são de grande importância no estabelecimento dos padrões reprodutivos e, consequentemente, no desenvolvimento de protocolos para a reprodução assistida nas diferentes espécies. Uma correlação direta entre o peso do testículo e a população espermática é observada nas diferentes espécies já estudadas, uma vez que o tamanho do testículo reflete principalmente o volume total do túbulo seminífero, seu principal componente. O presente trabalho tem como objetivos definir parâmetros volumétricos testiculares e correlacionar os dados de morfometria testicular e do túbulo seminífero com a massa corporal em seis cachorros-domato adultos. O peso corporal médio dos cachorros-do-mato foi de 6,53 Kg, dos quais cerca de 0,068\% são alocados em massa testicular e 0,042\% especificamente em túbulos seminíferos, que representam 87,5\% do parênquima testicular. A albugínea representa 12,5\% da massa testicular. O diâmetro médio dos túbulos seminíferos em cachorro-do-mato foi de $236 \mu \mathrm{m}$, e a espessura média do epitélio seminífero foi de $62,9 \mu \mathrm{m}$, sendo encontrados em média 18 metros de túbulo seminífero por grama de testículo. Os valores para os parâmetros tubulares indicam uma produtividade espermática próxima àquelas observadas nos carnívoros já estudados.

Palavras - chave: Morfologia, testículos, cachorro-do-mato, Cerdocyon thous, índice gonadossomático.

Recebido para publicação em janeiro de 2008 e aprovado em agosto de 2010.

Biologist, MSc. Departamento de Veterinária, Universidade Federal de Viçosa, Av. P.H. Rolfs, s/n, , Campus Universitário, 36570-000, Viçosa-MG, Brasil. biancaccaldeira@yahoo.com.br; maytebio@yahoo.com.br; pamellakelly@yahoo.com

${ }^{2}$ Veterinarian, DS. Departamento de Veterinária, Universidade Federal de Viçosa, Av. P.H. Rolfs, s/n, Campus Universitário, 36570-000, Viçosa-MG, Brasil. tarcizio@ufv.br

${ }^{3}$ Paramedical, DS. Departamento de Biologia Animal, Universidade Federal de Viçosa, Av. P.H. Rolfs, s/n, Campus Universitário, 36570-000, Viçosa-MG, Brasil. smatta@ufv.br 


\section{INTRODUCTION}

The crab-eating fox (Cerdocyon thous Linnaeus, 1766), also known as the forest fox, common fox and the common zorro, and, in Brazil, as cachorro-do-mato, raposacaranguejeira, lobinho, and graxaim-do-mato, is relatively common in Colombia, Venezuela, Guyana, Surinam, eastern Peru, eastern Bolivia, Paraguay, Uruguay, northern Argentina and in most habitats of Brazil (Fowler, 2001). The species occupies mainly the biomes Cerrado, Caatinga, Pantanal, Atlantic and Southern Plains, using forest edges, and altered areas inhabited by humans (Fonseca et al., 1996). The abundance of the crab-eating fox is due in part to its eating habit. It is an omnivorous species whose diet includes everything from insects, rodents, reptiles, birds, river crabs, eggs and even fruit (Bisbal \& Ojasti, 1980). Thanks to the high consumption of fruits, this species can act as seed dispersers (Rocha et al., 2004).

The crab-eating fox is listed in Appendix II of the Conservation on International Trade in Endangered Species (CITES, 2007). It has a high occurrence in nature and is assigned at the Least Concern category regarding the extinction risk. However, according to Vieira (1996), death by road accidents of crab-eating fox individuals occurs in a considerable amount and may contribute to large impacts on populations of this species.

With regard to reproductive characteristics, a positive correlation has been reported between testicular weight and sperm production (Amann, 1970; Olar et al., 1983; França \& Russell, 1998). However, testicular size is proportional to body size, i.e., somatic investment in gonadal mass is greater in small animals compared with larger ones (Kenagy \& Trombulak, 1986). The amount of sperm produced is always much larger than the number required for fertilization, and the fact that the testis size is not, necessarily, proportional to the body size contributes to energy saving, since large animals would produce excessive high amounts of sperm (Paula, 1999).

According to Kenagy \& Trombulak (1986), the relative testis size can provide information on the reproductive physiology and even on the mating system. Thus, testicular size is directly related to reproductive behavior, as monogamous and polygamous animals have lower gonadosomatic index (GSI) compared with species with promiscuous or polyandrous mating. In the first case, the small testicular investment reflects the formation of pairs or harems where one male is responsible for copulations. Among promiscuous or polyandrous animals, several males have access to copulation with the same female, being better able to paternity the animals with high sperm production and, hence, increased testicular size.

Seminiferous tubules are usually the most abundant components of the testicular parenchyma. All quantitative parameters related to seminiferous tubules, such as tubular diameter, thickness of the seminiferous epithelium and the total length per gram of testis have a positive relationship with spermatogenic activity (França \& Russell, 1998; Paula, 1999). Tubular measurement is, thus, the approach traditionally used as indicator of spermatogenic activity in investigations of testicular function (Navarro et al., 2004; Souza et al., 2005; Silva Jr et al., 2006; Mascarenhas et al., 2006).

The study of testicular morphophysiology and body biometry in wild animals allows the establishment of physiological and behavioral patterns important to understand aspects of the reproductive biology of different species, which make it possible to develop protocols for assisted reproduction. In this context, the objective of this work was to determine testicular volume parameters such as gonadosomatic index and volume of testicular parenchyma, compare the GSI with the tubulossomatic index (STI) between monogamous or polygamous species and promiscuous or polyandrous species, as well as to evaluate the seminiferous tubule diameter, the thickness of the seminiferous epithelium, seminiferous tubule length per gram of testis and the total length of seminiferous tubule in six adult crab-eating foxes .

\section{MATERIALAND METHODS}

Testicular fragments were collected from six adult crabeating foxes (Cerdocyon thous Linnaeus, 1766). These animals are routinely found hit by motor vehicles on highways in the vicinities of Viçosa (state of Minas Gerais, Brazil, $20^{\circ} 45^{\prime}$ S, $42^{\circ} 51^{\prime}$ W, 693 m.a.s.l.) and, some are taken to the Screening Center for Wild Animals, Federal University of Viçosa (UFV-CETAS). The animals who survive the trauma of being hit are rehabilitated and released, when possible, near the areas of occurrence. The procedures adopted in the methodology of this study were approved by the Ethics Committee of the Veterinary Department, Federal University of Viçosa-UFV, process no. $65 / 2007$.

As we are dealing with animals of the Brazilian fauna, the experiment was conducted under permission of the Brazilian Institute of Environment and Natural Resources (IBAMA) number 11373-1.

Two animals were anesthetized using darts containing $10 \mathrm{mg} / \mathrm{kg}$ tiletamine-zolazepam. The whole procedure was monitored by assessing animals' temperature, respiratory movements and heart rate every 10 minutes. The animals were weighed and it was taken the measures of width, thickness and length of the testis using a digital caliper.

The testicular volume was calculated using the formula (4/3) $\pi$ ABC, where $A=$ half the width, $B=$ half the 
thickness and C = half the length (Moreira, 1995; GuiãoLeite et al., 2006; Sarti, 2006; Mascarenhas et al., 2006; Bittencourt et al., 2007; Barros et al., 2007). The testicular volume was directly converted into grams, once the volume density of the testis in mammals is very close to one (Johnson et al., 1981; Paula, 1999).

The gonadosomatic index (GSI) was calculated using of the weight of both testis as a proportion of the total body weight, which represents the percentage of body mass allocated to the testis.

After trichotomy and local antisepsis, the scrotal skin was incised using a $4 \mathrm{~mm}$ diameter circular scalpel and a fragment was excised from the mid-region of the right or left testicle. The incision was sutured in separate layers with absorbable synthetic thread, using buried intradermal suture on the skin. Each animal received antiphlogistic agents and antibiotics in the postoperative treatment.

The animals that died during hospitalization $(n=4)$ were weighed and had their testis removed. The excised testis were measured following the previously described methodology and fragments were collected from their midregion.

The samples were immediately fixed in Karnovsky's fixative (4\% paraformaldehyde and $4 \%$ glutaraldehyde in $0.1 \mathrm{M}$ phosphate buffer, $\mathrm{pH}$ 7.4) at room temperature for at least two hours, and subsequently stored in the same buffer under refrigeration.

For light microscope studies, fragments were dehydrated in an ethanol series of increasing concentration (70, 80, 90 and 100\% GL) and then embedded in plastic resin (Leica Historesin ${ }^{\circledR}$ ). The fragments were positioned to allow cross sections of the testicular albuginea. Sequential histological sections (3- $\mu \mathrm{m}$ thick) were obtained using a rotary microtome (Leica RM2155®) with a glass knife and stained with $1 \%$ toluidine blue/ sodium borate, for one minute.

The mean thickness of the testicular albuginea was determined in 20 cross sections of each animal, using a light microscope in combination with an ocular micrometer (20-fold magnification). The volume of the testicular albuginea was estimated by subtracting the volume of testicular parenchyma from the total testicular volume. The volume of testicular parenchyma was also calculated using the volume formula for an ellipse, by subtracting the testicular size from the thickness of the albuginea. When possible, the testicular albuginea was dissected and its thickness measured, using a digital caliper with resolution of $0.01 \mathrm{~mm}$. The data showed no significant difference from values obtained by a light microscope.

Ten random histological images obtained by photomicroscope (200-fold magnification) were used to calculate the volume proportion occupied by seminiferous tubules and the intertubular space. A graticule with 400 intersections was superimposed on the images. The intersections overlying the seminiferous tubule and intertubular space were counted. Using the volume proportion of the seminiferous tubule and intertubular space, we calculated the total volume of these testicular components.

The mean diameter of the seminiferous tubules was estimated by measuring 20 tubule cross sections, made as circular as possible, of each animal. Measurements were taken using an ocular micrometer in a light microscope and a 20X objective lens. In the same sections, we also measured the height of the seminiferous epithelium, from the basal membrane to the luminal edge. The length of the seminiferous tubule was calculated using the volume formula for a cylinder, where the length is the volume divided by the base area. Thus, the total volume of seminiferous tubules divided by the area of the cross section corresponds to the total length of seminiferous tubules per testis, which can also be converted to meters per gram of testis.

The tubulossomatic index (ITS) represents the percentage of body weight allocated to the seminiferous tubules. It was calculated by inferring to the gonadosomatic index (GSI) the percentage of the testicular parenchyma occupied by seminiferous tubules.

Data were analyzed by descriptive statistics, where mean, standard deviation and coefficient of variation were calculated by using the statistical functions of Microsoft Office Excel ${ }^{\circledR} 2003$.

\section{RESULTS AND DISCUSSION}

The mean body weight of the studied animals was $6.53 \mathrm{~kg}$ (Table 1), within the range considered normal for the species (5 to $8 \mathrm{~kg}$ ) (Brady, 1979). The testicular weight was estimated from the testis dimensions, once for this work samples were taken by testicular biopsy. Testicular biopsy is the elective procedure to study reproductive morphophysiology in wild animals (Azevedo et al., 2006; Guião-Leite et al., 2006; Sarti, 2006), as it is a conservative method that maintains the reproductive capacity, showing no harmful effects on sperm production in the long term (Lopate et al., 1989; Threlfall \& Lopate, 1993; Attia et al., 2000). Unilateral testicular biopsy in dogs of undetermined breed (mongrel dog) showed no changes in the cell population, the intrinsic efficiency of the spermatogenic process and the Sertoli cell index, either in the biopsied testis or in the contralateral testis, after a period of 60 days (Mascarenhas et al., 2006).

According Kenagy \& Trombulak (1986), the largest allocation to testicular mass is found in smaller animals, compared with animals of large body mass. This explains the close similarity of GSI of crab-eating fox $(0.068 \%$, Table 1$)$ and domestic cats (0.07\%, Godinho, 1999), which 
Table 1. Body weight, right testis weight, left testis weight, weight of both testis and gonadosomatic index of the crab-eating fox

\begin{tabular}{lccccc}
\hline Animal & $\begin{array}{c}\text { Body weight } \\
\mathbf{( k g )}\end{array}$ & $\begin{array}{c}\text { Right testis } \\
\text { weight } \mathbf{( g )}\end{array}$ & $\begin{array}{c}\text { Left testis } \\
\text { weight } \mathbf{( g )}\end{array}$ & $\begin{array}{c}\text { Weight of both } \\
\text { testis } \mathbf{( g )}\end{array}$ & $\begin{array}{c}\text { Gonadosomatic } \\
\text { index (\%) }\end{array}$ \\
\hline 1 & 9.85 & 3.53 & 3.68 & 7.22 & 0.073 \\
2 & 6.00 & 1.95 & 1.76 & 3.71 & 0.062 \\
3 & 4.60 & 2.10 & 2.10 & 4.20 & 0.091 \\
4 & 4.20 & 1.90 & 1.90 & 3.80 & 0.090 \\
5 & 6.53 & 1.52 & 1.65 & 3.18 & 0.049 \\
6 & 8.00 & 1.58 & 1.70 & 3.28 & 0.041 \\
Mean $\pm \mathrm{SD}^{\mathrm{a}}$ & $6.53 \pm 2.13$ & $2.09 \pm 0.73$ & $2.13 \pm 0.78$ & $4.23 \pm 1.51$ & $0.068 \pm 0.021$ \\
$\mathrm{CV}^{\mathrm{b}}$ & 32.6 & 35.1 & 36.5 & 35.7 & 31.0 \\
\hline
\end{tabular}

a Standard Deviation

b Coefficient of Variation.

are higher than GSI of larger animals such as the maned wolf (0.04\%, Bittencourt et al., 2007), the jaguar (0.034\%, Azevedo et al., 2006), the African lion (0.015\%, Barros, 2005) and the puma (0.03\%, Guião-Leite \& Paula, 2003).

Kenagy \& Trombulak (1986) also discussed that the relative testis size reflects the mating system of a given species, i.e., the testis size is directly related to the reproductive behavior. Monogamous and polygamous animals have lower GSI in relation to promiscuous or polyandrous species. In the former case (monogamy and polygamy), the male competition for the production of genetic offspring is by access to females, whereas for promiscuous and polyandrous species, the male competition for production of offspring occurs within the female genital tract and, thus, males with higher sperm production and consequently, with larger relative testis size are better able to paternity. The crab-eating fox is a monogamous species in which mating can occur at any time of the year (Cheida et al., 2006). Hence, it is expected that the GSI of crab-eating fox is lower than species of polyandrous or promiscuous behavior, as is the case of the domestic dog, which although showing mean body size higher than the crab-eating fox, it has higher IGS (0.1\%, Mascarenhas et al., 2006). This also seems to be the case observed in ocelots that, even having twice the body weight recorded for the crab-eating fox, it shows a much higher GSI (0.12\%, Sarti, 2006). However, further ethological studies on this species are needed to validate this statement.

In most domestic species, the volume proportion of the albuginea and mediastinum testis is usually around 10\% (França \& Russell, 1998). The animals evalueted in this study had mean volume proportion of testicular albuginea of $12.5 \%$ (Table 2), very close to that recorded for maned wolves (11\%, Bittencourt, 2003). But other studied carnivores show a higher proportion of testicular albuginea, domestic cats, for instance, show values near 18\% (Godinho, 1999). Mascarenhas et al. (2006) reported similar values for dogs of undetermined breed and Barros (2005) for African lions, whereas the ocelot has the highest proportion of albuginea among carnivore studied species, with an average of 23.42\% (Sarti, 2006).

Although testicular parenchyma is not an entirely appropriate term to name the testis devoid of albuginea and mediastinum, it is widely mentioned in the literature (Berndtson, 1977; Johnson et al., 1981; Russell et al., 1990a; Johnson et al., 2000). The testicular parenchyma can be divided into two compartments: tubular and intertubular (Amann, 1970; Fawcett et al., 1973; Amann \& Schanbacher, 1983; Russell et al., 1990b). The intertubular compartment consists of Leydig cells, blood vessels, lymph vessels, nerves and a varied population of cells that includes fibroblasts, macrophages and mast cells (Russell, 1996). The crab-eating fox allocates $12.7 \%$ of the testicular parenchyma to the intertubular tissue (Table 3), lower than the values recorded for the ocelot (19.39\%;

Table 2. Volume of testicular parenchyma, albuginea thickness, albuginea volume and albuginea of the adult crab-eating fox

\begin{tabular}{lc}
\hline Parameter & $\begin{array}{c}\text { Means } \pm \\
\text { standard } \\
\text { deviations }\end{array}$ \\
\hline Volume of testicular parenchyma $(\mathrm{mL})$ & $3.70 \pm 1.77$ \\
Albuginea thickness $(\mathrm{cm})$ & $0.034 \pm 0.003$ \\
Albuginea volume $(\mathrm{mL})$ & $0.53 \pm 0.17$ \\
Albuginea $(\%)$ & $12.5 \pm 1.4$ \\
\hline $\mathrm{N}=6$ &
\end{tabular}

Table 3. Volume proportion of seminiferous tubules, volume proportion of intertubular tissue, total volume of the seminiferous tubule and total volume of the intertubular tissue in crab-eating fox

\begin{tabular}{lc}
\hline Parameter & $\begin{array}{c}\text { Means } \pm \\
\text { standard } \\
\text { deviations }\end{array}$ \\
\hline Volume proportion of seminiferous tubules (\%) & $87.5 \pm 5.2$ \\
Volume proportion of intertubular tissue (\%) & $12.7 \pm 5.3$ \\
Total volume of the seminiferous tubule (mL) & $3.23 \pm 1.28$ \\
Total volume of the intertubular tissue (mL) & $0.47 \pm 0.05$ \\
\hline $\mathrm{N}=6$ &
\end{tabular}


Sarti, 2006), the maned wolf (19.97\%; Bittencourt et al., 2007), the puma (21.88\%; Guião-Leite et al., 2006), the jaguar (22.7\%; Azevedo et al., 2006) and the African lion (24.3\%; Barros, 2005). The tubular compartment is the main component of the testis in most mammals, with great influence on the testicular weight and sperm production (Amann, 1970; França \& Russell, 1998; Paula et al., 2007). Except for the low values reported for the marmot and the capybara (Russell et al., 1990b; Paula et al., 2007), the majority of animals investigated had between 70 and $90 \%$ of seminiferous tubules in the testicular parenchyma (França \& Russell, 1998 ). The mean volume of seminiferous tubules observed in the crab-eating fox was $3.23 \mathrm{~mL}$ in both testis, representing on average $87.5 \%$ of the testicular parenchyma (Table 3), which is close to $90 \%$ reported for the domestic cat (Godinho, 1999), but higher than the values reported for the ocelot (80.58\%; Sarti, 2006), the maned wolf, (79.3\%; Bittencourt et al., 2007), the puma (78\%; GuiãoLeite et al., 2006), the jaguar (77.7\%; Azevedo et al., 2006) and the African lion (75.6\%; Barros, 2005).

Tubulossomatic Index (STI) is a parameter used to quantify the investment in seminiferous tubules in relation to body mass. This parameter allows for more discussion on the influence of reproductive behavior on the testicular morphology. Thus, species known to be monogamous or polygamous, such as the maned wolf and the large cats, show less tubulossomatic investment than promiscuous or polyandrous species, such as domestic dogs and cats (Table 4). The crab-eating fox allocates on average $0.042 \%$ of body weight to seminiferous tubules (Table 4), this value, as expected, is closer to those of species with monogamous and polygamous behavior than to promiscuous and polyandrous species (Table 4). The ocelot has the highest STI among wild carnivores (mean of $0.074 \%$; Sarti, 2006), which is higher than the value found for the domestic cat (0.063\%; Godinho, 1999). This demonstrates a greater investment in sperm production than expected for an animal of its size and points to the need for further studies on their reproductive behavior.
Tubular measurement is one of the approaches used as indicators of spermatogenic activity in experiments related to testicular function (Navarro et al., 2004; Souza et al., 2005; Silva Jr et al., 2006; Mascarenhas et al., 2006). Although the mean tubular diameter can reach $550 \mu \mathrm{m}$ in some marsupial species (Woolley, 1975), in most amniotes it varies from 180 to $300 \mu \mathrm{m}$ (Roosen-Runge, 1977). The seminiferous tubule diameter remains relatively constant in non-seasonal, sexually mature animals (Paula, 1999; Guião-Leite, 2002). The value of production observed in domestic animals varies from 170 to $277 \mu \mathrm{m}$ (França \& Russell, 1998). The crab-eating fox shows mean of 236 $\mu \mathrm{m}$ (Table 5), close to the value found for the puma (227.37 $\mu \mathrm{m}$; Guião-Leite, 2002), the maned wolf (227.35 $\mu \mathrm{m}$; Bittencourt, 2003), the ocelot (211.35 $\mu \mathrm{m}$; Sarti, 2006), the jaguar (257.07 $\mu \mathrm{m}$; Azevedo, 2004) and the African lion (252.72 $\mu \mathrm{m}$; Barros, 2005).

Wing \& Christensen (1982) reported that the measurement of seminiferous epithelium was more effective for sperm production evaluation than the tubular diameter. The mean thickness of the seminiferous epithelium in the crab-eating fox was $62.9 \mu \mathrm{m}$ (Table 5), which is within the range reported for domestic animals (60 to $100 \mu \mathrm{m}$; França \& Russell, 1998). Values larger than that of the crab-eating fox were reported for felines such as the puma (67 $\mu \mathrm{m}$; Guião-Leite, 2002), the ocelot (75.4 $\mu \mathrm{m}$; Sarti, 2006), the domestic cat ( $81 \mu \mathrm{m}$; Godinho, 1999), the jaguar (90.3; $\mu \mathrm{m}$ Azevedo, 2004) and the African lion (93.2 $\mu \mathrm{m}$; Barros, 2005).

Table 5. Seminiferous tubule diameter, thickness of the seminiferous epithelium, tubular length per gram of testis and total length of the seminiferous tubule in the crab-eating fox

\begin{tabular}{lc}
\hline Parameter & $\begin{array}{c}\text { Means } \pm \\
\text { standard } \\
\text { deviations }\end{array}$ \\
\hline Seminiferous tubule diameter $(\mu \mathrm{m})$ & $236 \pm 22$ \\
Thickness of the seminiferous epithelium $(\mu \mathrm{m})$ & $62.9 \pm 9.1$ \\
Tubular length per gram of testis $(\mathrm{m} / \mathrm{g})$ & $18.1 \pm 4.1$ \\
Total length of the seminiferous tubule $(\mathrm{m})$ & $80.5 \pm 46.1$ \\
\hline $\mathrm{N}=6$ &
\end{tabular}

Table 4. Comparative table of gonadosomatic index (GSI) and tubulossomatic index (STI), between monogamous or polygamous species and promiscuous or polyandrous species

\begin{tabular}{lccc}
\hline & Parameters & IGS (\%) & ITS (\%) \\
\hline Monogamous or polygamous species & Crab-eating-fox & 0.068 & 0.042 \\
& Maned wolf $^{1}$ & 0.040 & 0.030 \\
& Puma $^{2}$ & 0.030 & 0.020 \\
& Jaguar $^{3}$ & 0.034 & 0.022 \\
Promiscuous or polyandrous species & African lion $^{4}$ & 0.015 & 0.009 \\
& Domestic dog $^{5}$ & 0.100 & 0.080 \\
& Domestic cat $^{6}$ & 0.070 & 0.060 \\
& Ocelot $^{7}$ & 0.12 & 0.074
\end{tabular}

${ }^{1}$ Bittencourt (2003); ${ }^{2}$ Guião-Leite (2002); ${ }^{3}$ Azevedo (2004); ${ }^{4}$ Barros (2005); ${ }^{5}$ Paula \& Cardoso (1994); ${ }^{6}$ Godinho (1999); ${ }^{7}$ Sarti (2006). 
The crab-eating fox has on average 80 meters of seminiferous tubules in both testis (Table 5). There is great variation in testicular size among different species and hence the comparison considering the total length of the seminiferous tubule is not significant, whereas the tubular length per gram of testis is a more meaningful parameter for comparison among species. In this work, we recorded 18 meters of seminiferous tubule per gram of testis in the crab-eating fox (Table 5), which is close to values found in the puma (18.2m/g; Guião-Leite, 2002), the maned wolf (18m/g; Bittencourt, 2003) and the ocelot (17.81m/g; Sarti, 2006), but lower than those found in the domestic cat (23m/g; Godinho, 1999) and higher than the values reported for the jaguar (12.2m/g; Azevedo, 2004) and the African lion (12.4m/g; Barros, 2005).

\section{CONCLUSIONS}

The mean body weight of adult crab-eating foxes (Cerdocyon thous) was $6.53 \mathrm{~kg}$, of which around $0.068 \%$ is allocated to the testicular mass and $0.042 \%$ specifically to the seminiferous tubules.

The seminiferous tubules accounted for approximately $87.5 \%$ of the testicular parenchyma, which is within the range expected for medium sized, monogamous animals. The testicular albuginea represents about $12.5 \%$ of the testis weight.

The mean diameter of seminiferous tubules was 236 $\mu \mathrm{m}$ and the thickness of the seminiferous epithelium was $62.9 \mu \mathrm{m}$. The crab-eating fox showed about 18 meters of seminiferous tubule per gram of testis and the values of the tubular parameters indicate sperm productivity similar to previously studied carnivores.

\section{REFERENCES}

Amann RP (1970) Sperm production rates. In: Johson, AD, Gomes, WR \& Vandemark, NL (Eds). The testis. New York, Academic Press. p.433-482.

Amann RP |\& Schanbacher BD (1983) Physiology of male reproduction. Journal of Animal Science Supplemment, 57:380403.

Attia KA, Zaki AA, Eilts BE, Paccamont DL, Hosgood G, Dietrich MA, Horohov,DW \& Blowin DC (2000) Anti-sperm antibodies and seminal characteristics after testicular biopsy or epididymal aspiration in dogs. Theriogenology, 53:1355-1363.

Azevedo MHF (2004) Análise morfofuncional do testículo da onça pintada (Panthera onca) adulta. Dissertação de Mestrado. Universidade Federal de Viçosa, Viçosa. 63p.

Azevedo MHF, Paula TAR, Matta SLP, Fonseca CC \& Neves MTD (2006) Morfometria testicular e o túbulo seminífero da onça pintada (Panthera onca). Revista Ceres, 53:374-381.

Barros JBG (2005) Análise morfofuncional do testículo e espermatogênese de leões africanos (Panthera leo, Linnaeus, 1758) adultos. Dissertação de Mestrado. Universidade Federal de Viçosa, Viçosa. 65p.
Barros JBG, Paula TAR, Matta SLP, Fonseca CC, Leite FLG, Júnior JLR, Oliveira PC \& Costa EP (2007) Sertoli cell index and spermatic reserves in adult captive african lions (Panthera leo, Linnaeus, 1758), Animal Reproduction Science. doi:10.1016/ j.anireprosci.2007.04.002

Berndtson WE (1977) Methods for quantifying mammalian spermatogenesis: a review. Journal of Animal Science, 44:818883.

Bisbal FJ \& Ojasti J (1980) Nicho trofico del zerro Cerdocyon thous (Mammalia, Carnivora). Venezuelica, 10:469-496.

Bittencourt VL (2003) Avaliação morfofuncional do testículo e do processo espermatogênico do lobo guará (Chrysocyon brachyurus, Illiger, 1811), adulto. Dissertação de Mestrado. Universidade Federal de Viçosa, Viçosa. 57p.

Bittencourt VL, Paula TAR, Matta SLP, Fonseca CC, Costa DS, Benjamin LA \& Costa EP (2007) The seminiferous epithelium cycle and daily spermatic production in the adult maned wolf (Chrysocyon brachyurus, Illiger, 1811). Micron, 38:584-589.

Brady CA (1979) Observations on the behavior and ecology of the crab-eating fox (Cerdocyon thous). In: Eisenberg, JF (Ed) Vertebrate ecology in the Northern Neotropics. Washington, Smithsonian Institution Press. 271p.

CITES (Conservation on International Trade in Endangered Species) protected species. Disponível em: http://www.cites.org/ cites/eng/append. Accesson March, 152007.

Cheida CC, Nakano-Oliveira E, Costa FR, Rocha-Mendes F \& Quadros J (2006) In: Mamíferos do Brasil. Londrina, Nélio dos Reis. p.244-245.

Fawcett DW, Neaves WB \& Flores MN (1973) Comparative observations on intertubular lymphatic and the organization of the interstitial tissue of the mammalian testis. Biology of Reproduction, 9:500-532.

França LR \& Russell LD (1998) The testis of domestic animals. In: Male reproduction: a multidisciplinary overview. Madrid, Churchill Livingstone. p.197-219.

Fonseca GAB, Hermann G, Leite YLR, Mittermeier RA, Rylands AB \& Patton JL (1996) Lista anotada de mamíferos do Brasil. Occasional Papers in Conservation Biology, 4:1-38.

Fowler ME (2001) Biology, medicine, and surgery of South American wild animals. Ames, Iowa State University Press. 536p.

Godinho CL (1999) Análise histométrica do testículo e duração da espermatogênese em gatos (Felis domestica) sexualmente maduros. Dissertação de Mestrado. Universidade Federal de Minas Gerais, Belo Horizonte. 123p.

Guião-Leite FL (2002) Análise morfológica do testículo e do processo espermatogênico da onça parda (Puma concolor) adulta. Dissertação de Mestrado. Universidade Federal de Viçosa, Viçosa. 64p.

Guião-Leite FL \& Paula TAR (2003) Rendimento intrínseco da espermatogênese, o índice de células de Sertoli e a produção espermática diária da onça parda (Puma concolor). Revista Brasileira de Reprodução Animal, 27:21-26.

Guião-Leite FL, Paula TAR, Matta SLP, Fonseca CC, Neves MTD \& Barros JBG (2006) Cycle and duration of the seminiferous epithelium in puma (Puma concolor). Animal Reproduction Science, 91:307-316.

IBAMA (Instituto Brasileiro do Meio Ambiente e Recursos Naturais Renováveis). Lista oficial de animais ameaçados de extinção (2007). Disponível em: http://www.ibama.gov.br. Access on March 15, 2007.

Johnson L, Petty CS \& Neves WB (1981) A new approach to qualification of spermatogenesis and its application to germinal cell attrition during human spermatogenesis. Biology of Reproduction, 25:217-226. 
Johnson L, Varner DD, Roberts ME, Smith TL, Keillor GE \& Scrutchfield WL (2000) Efficiency of spermatogenesis: a comparative approach. Animal Reproduction Science, 6061:471-480.

Kenagy GJ \& Trombulak SC (1986) Size and function of mammalian testis in relation to body size. Journal of Mammalogy, 67:1-22.

Lopate C, Threlfall WR \& Rosol TJ (1989) Histopatologic and gross effects of testicular biopsy in the dog. Theriogenology, 32:585-602.

Mascarenhas RM, Paula TAR, Matta SLP, Lanna LL, Fonseca CC \& Neves MTD (2006) Morfometria macro e microscópica e índices somáticos dos componentes testiculares de cães sem raça definida, da puberdade à senilidade. Revista Ceres, 53:106-112.

Moreira JR (1995) The reproduction, demography and management of capybaras (Hydrochoerus hydrochaeris) on Marajó Island Brazil. Tese de Doutorado. University of Oxford, Oxford. 198p.

Navarro RD, Paula TAR, Matta SLP, Fonseca CC \& Neves MTD (2004) Efeito da exposição pré e pós-natal ao ultra-som de baixa intensidade sobre a célula de Leydig e demais componentes do espaço intertubular do testículo de camundongos adultos. Revista Ceres, 51:445-455.

Olar TT, Amann RP \& Pickett BW (1983) Relationships among testicular size, daily production and output of spermatozoa and extragonadal spermatozoa reserves of the dog. Biology of Reproduction, 29:1114-1120.

Paula TAR (1999) Avaliação histológica e funcional do testículo de capivaras adultas (Hydrochoerus hydrochaeris). Tese de Doutorado. Universidade Federal de Minas Gerais, Belo Horizonte. 84p.

Paula TAR \& Cardoso FM (1994) Alterações etárias na espermatogênese do cão. I. análise histométrica. Arquivo Brasileiro de Medicina Veterinária e Zootecnia, 46:19-30.

Paula,TAR, Matta SLP, Silva Jr VA, Costa DS, Fonseca CC \& Neves MTD (2007) Intertubular space characterization in adult capybara (Hydrochoerus hydrochaeris) testis. Brazilian Archives of Biology and Technology, 50: 289-297.

Rocha VJ, Reis NR \& Sekiama ML (2004) Dieta e dispersão de sementes por Cerdocyon thous (Linnaeus) (Carnívora, Canidae) em um fragmento florestal no Paraná, Brasil. Revista Brasileira de Zoologia, 21:871-876.
Roosen-Runge EC (1977) The process of spermatogenesis in animals. Cambridge, University Press. 78 p.

Russell LD (1996) Mammalian Leydig cell structure. In: Payne AH, Hardy MP \& Russell LD (eds). The Leydig cell. Vienna, Cache River Press. cap. 10, p.218-222.

Russell LD, Ren HP, Sinha Hikim I, Schulz W \& Sinha Hikim AP (1990a) A comparative study in twelve mammalian species of volume densities, volumes and numerical densities of selected testis components, emphasizing those related to the Sertoli cell. American Journal of Anatomy, 188:21-30.

Russell LD, Ettlin RA, Sinha Hikim EP \& Clegg ED (1990b) Histological and histopathological evaluation of the testis. New York, Cache River Press. 286p.

Sarti P (2006) Avaliação morfométrica do testículo e da espermatogênese de jaguatiricas (Leopardus pardalis, Linnaeus, 1758) adultas. Dissertação de Mestrado. Universidade Federal de Viçosa, Viçosa. 56p.

Silva Jr VA, Vieira CFP, Paula TAR, Palma MB, Amorim AA \& Manhâes RC (2006) Neonatal treatment with naloxone increasses the population of Sertoli cells and sperm production in adult rats. Reproduction Nutrition Development, 46:157166.

Souza PC, Paula TAR, Natali AJ, Matta SLP, Costa DS, Fonseca CC \& Sarti P (2005) Efeito do exercício crônico voluntário e do sedentarismo, com e sem o uso do esteróide anabólico nandrolona, sobre os componentes do parênquima testicular de ratos adultos. Revista Ceres, 53:305-316.

Threlfall WR \& Lopate C (1993) Testicular biopsy. In: McKinnon AO \& Voss J (Eds.) Equine Reproduction. Philadelphia, Blackwell Publishing Limited. p.943-949.

Vieira EN (1996) Highway mortality of mammals in central Brazil. Ciência e Cultura, 48:270-272.

Wing TY \& Christensen AK (1982) Morphometric studies on rat seminiferous tubule. American Journal of Anatomy, 165:13-25.

Woolley P (1975) The seminiferous tubules in dasyurid marsupials. Journal of Reproduction Fertility, 45:255-261. 